\title{
Diallyl trisulfide (DATS) abrogates arsenic induced testicular oxidative stress in rats
}

\author{
Sumedha NC, Miltonprabu S* \\ Department of Zoology, Annamalai University, Annamalainagar-608002, Tamilnadu, India \\ *Corresponding author E-mail: smprabu73@gmail.com
}

\begin{abstract}
Background: Arsenic is an emblematic heavy metal and enters the animals through intake of arsenic contaminated water and gets stored in primitive organs.

Aim: The present study was designed to investigate the protective effect of diallyl trisulfide (DATS) on arsenic (As) induced testicular oxidative stress in male rats.

Methods: Experimental rats were randomly divided into four groups and treated orally for 28 days: control, as $(5 \mathrm{mg} / \mathrm{kg} / \mathrm{bw})$ treated, DATS $(80 \mathrm{mg} / \mathrm{kg} / \mathrm{bw})+$ As treated and DATS $(80 \mathrm{mg} / \mathrm{kg} / \mathrm{bw})$ alone treated rats. Testicular toxicities were recorded by plasma hormonal analysis, sperm function test, estimation of testicular oxidative stress markers, biochemical analysis, antioxidant enzymes and nonantioxidant enzymes and histopathological changes.

Results: Short term exposure to as resulted in decreased testicular - weight; sperm count, plasma hormonal concentration and significantly increased levels of oxidative stress markers, testis ALP, ACP and cholesterol with a significant decreased in the enzymatic antioxidant, non-antioxidant enzymes and ATPases enzymes when compared to the control group. Pre-administration of DATS to as treated rats were found to protect against adverse changes in the reproductive organ weight, sperm count, enhance plasma hormone level along with restored antioxidant enzymes, non-antioxidant enzymes and ATPases enzymes supporting with revived histological structure of testes.

Conclusion: Our results show that DATS exerts a protective effect against as induced testicular toxicity associated with reduced testicular oxidative stress as evidenced by the clear restoration of plasma hormone levels and antioxidant activities.
\end{abstract}

Keywords: Arsenic, Diallyl Trisulfide, Oxidative Stress, Rat, Testis.

\section{Introduction}

Arsenical compounds are environmental contaminant with manifold effects in animal and human populations. Human are exposed to arsenic mainly through water, food and drugs. The repeated use of arsenic is as herbicides, insecticides, rodenticides and food preservatives (Mehranjani and Hemadi 2007). Though adverse, on the other hand, reality relics that a large number of populations in some areas of the world are drinking arsenic-contaminated ground water and the number of cases torment from As-induced organ dysfunctions are increasing terrifically (Das et al. 2009). Arsenic is a major environmental chemical and a known reproductive toxicant via the depression of spermatogenesis and androgenesis in males (Morakinyo et al. 2010). Arsenic is also extremely sensitive in the process of reproduction, leading to increased rates of abortion in women and infertility in man (Skakkeback et al. 1991).

Arsenic affects the mitochondrial enzymes, impairs the cellular respiration and causes cellular toxicity. It can also substitute phosphate intermediates, which could theoretically slow down the rate of metabolism and interrupt the production of energy. Male infertility is reflected by low sperm count, low sperm motility and bad quality of sperms (Sarkar et al. 2003). Arsenic has been found to have an inhibitory effect on the activity of testicular steroidogenic enzyme D5-3b- hydroxysteroid dehydrogenase (D5-3b-HSD) and 17ß-hydroxysteroid dehydrogenase (17B-HSD) and to reduce the weight of the testes and accessory sex glands in rats (Ali et al 2013). High As level may suppress the sensitivity of gonadotroph cells to GnRH (Gonodotropin releasing hormone) as well as gonadotropin secretion by elevating plasma levels of glucocorticoids (Ali et al. 2013). These ultimately lead to the development of gonadal toxicity.

Arsenic exposure has also been associated with severe metabolic disorders, including reproductive toxicity. Male germ cells may be susceptible to oxidative stress because of high concentration of polyunsaturated fatty acids and low antioxidant capacity. Arsenic exerts its toxicity by generating reactive oxygen species (ROS) during redox cycling and metabolic activation processes that causes tissue damages. Free radicals damage biomembrane, reflected by increased lipid peroxidation oxidation of nucleic acid and protein, thereby compromising cellular integrity and function. In the testes enhanced production of ROS causes significant alteration in tissue physiology, spermatogenic process or induces oxidative damage to DNA, which is potential risk to offspring (Sharma and Kumar 2011).

At the same time, renewed attention has been created due to the therapeutic application of arsenic in the treatment of lymphoid and hemopoietic neoplasms such as acute promyelocytic leukemia (Das et al. 2009). Arsenic has been found to impair male reproductive function like spermatogenesis and testosterone release, inhibited testicular enzyme function, and reduced the weight of the male sex organs (Sarkar et al. 1991) probably by inducing oxidative stress (Chang et al. 2007). However, the mechanism(s) by which arsenic impairs male reproductive function remains unclear. Emerging evidence from the literature supports the role of free 
radical and reactive oxygen species (ROS) mediated oxidative stress in the pathophysiology of As-mediated organ injury and cell death (Das et al. 2009).

Very little is, however, known about the use of antioxidants as the possible preventive or curative agents that can be targeted as therapeutic tools in testicular abnormalities. The conditional organosulfur compounds DATS, of garlic could be considered as a potent candidate in this regard as this organosulfur compound can chelate with as and it scavenges free radical. Diallyl trisulfide (DATS) is the second most abundant organosulfur constituent in garlic oil and accounts for about 30-35\% of total organosulfur compounds (Sumedha and Miltonprabu 2013).

No meticulous in vivo studies have been performed on the effect of DATS on As-induced impairment of testicular functions. So the aim of the present study was, therefore, undertaken to investigate the protective role of DATS against As-induced testicular oxidative impairment. The oxidative damage caused by As and the protective role of DATS were evaluated by measuring the activities of intracellular antioxidant enzymes, intracellular concentration of ROS, testicular sperm count, activities of the testicular steroidogenic enzymes, etc.

\section{Materials and methods}

\subsection{Chemicals and reagents}

Diallyl trisulfide was purchased from Lukang Cisen Pharmaceutical Co., Ltd. (Shangdong, China). Arsenic was obtained from Sigma Chemical Co. (St. Louis, MO, USA). All other fine chemicals, reagents and solvents were of certified analytical grade and purchased from S.D. Fine Chemicals, Mumbai or Himedia Laboratories Pvt. Ltd., Mumbai, India. Reagent kits were obtained from span diagnostics, Mumbai, India.

\subsection{Animals}

Male albino rats weighing 180-190 g were used in this study They were maintained in an environmentally controlled animal house (temperature $24 \pm 2{ }^{\circ} \mathrm{C}$ ) with a $12 \mathrm{~h}$ light/dark schedule and free access to deionized drinking water. The animal treatment and protocol employed were approved by the Institutional Animal Ethics Committee, Annamalai University (Registration Number: 885/2012/CPCSEA).

\subsection{Experimental design}

In the present study, sodium arsenate was administered intragastrically at a dose of $5 \mathrm{mg} / \mathrm{kg}$ body weight/day for 4 weeks and DATS was administered 90 minutes before the administration of As. In the experiment, a total of 30 rats was used. The rats were divided into 5 groups of 6 rats each.

Group 1: Control rats treated with normal saline and corn oil for 28 days.

Group 2: Rats received as sodium arsenate $(5 \mathrm{mg} / \mathrm{kg}$ body weight) in normal saline for 28 days.

Group 3: Rats received as (5mg/kg body weight) with oral preadministration of DATS $80 \mathrm{mg} / \mathrm{kg}$ body weight) for 28 days

Group 4: Normal rats received DATS $(80 \mathrm{mg} / \mathrm{kg}$ body weight) dissolved in corn oil and administered orally for 28 days.

At the end of the experimental duration, rats were fasted overnight and sacrificed by decapitation. Blood samples were collected through cardiac puncture and plasma was separated for hormonal analysis.

\subsection{Sample collection}

The testes were expurgated cleared of adhering connective tissues, weighed and homogenized in ice cold $1.15 \% \mathrm{KCL}-0.01 \mathrm{M}$ sodiumpotassium phosphate buffer $\left(\mathrm{p}^{\mathrm{H}} 7.4\right)$ using a Potter-Elvehjem type Homogenizer. The homogenates were then centrifuged at 5000rpm for $15 \mathrm{~min}$ at $4{ }^{\circ} \mathrm{C}$ and the resultant supernatants were used for biochemical assays.

\subsection{Biochemical analysis of testis tissue}

The acid phosphatase (AcP) and alkaline phosphatase (AlP) activity in the testis was estimated by the method of Fiske and Subbarow (1925)

The Leiberman Burchard method given by the King and Wolten (1959) is used for estimating Cholesterol content in testis tissue. A pinkish to brown color give rise when the phenenthrene ring of cholesterol reacts with $\mathrm{FeCl} 3$ and it is absorbed at $540 \mathrm{~nm}$. The concentration of cholesterol present is directly proportional to its intensity.

\subsection{Assay of plasma LH, FSH and testosterone concen- trations}

Plasma follicle - stimulating hormone (FSH), luteinizing hormone (LH) testosterone concentration were measured by enzyme linked immunosorbent assay (ELIZA) using ELIZA reader statfax-303 (Awareness comp. USA).LH and FSH concentration were measured as described (RADIM S.P.A. Rome, Italy), whereas Testosterone concentration was measured as described in the instruction provided with kits (DRG Diagnostic GmbH, Germany) in which endogenous horseradish peroxides conjugate for binding to the coated antibody.

\subsection{Epididymal sperm concentration and motility}

Epididymal sperm count and sperm progressive motility were evaluated by the method of Linder et al. (1986), accordingly, epididymal spermatozoa were obtained by mincing the epididymis with anatomical scissors in $5 \mathrm{ml}$ of physiological saline and incubated at $32{ }^{\circ} \mathrm{C}$ for 2 minute. An aliquot of this solution was placed in Neubauer haemocytometer and motile sperm were counted by using a microscope at $400 \mathrm{X}$ magnification. Non-motile sperm numbers were first determined, followed by counting of total sperm. Sperm motility was expressed as a percent of motile sperm of the total sperm counted. Percentages of morphologically abnormal spermatozoa were determined by the method described by Evans and Maxwell (1987). According to this method, slides were prepared with Wells and Awa attains for morphological examination and $1 \%$ eosin $\mathrm{B}$ and $5 \%$ nigrosine in $3 \%$ sodium citrate dehydrate solution for live/dead ratio. A total of 400 sperm cells was counted on each slide under a light microscope at 100X magnification.

\subsection{Estimation of antioxidant and glutathione metabo- lizing enzyme activities}

Superoxide dismutase (SOD) was assayed by the method of Kakkar et al. (1984), in which one unit of activity defined as the enzyme reaction, which gave $50 \%$ inhibition of nitrobluetetrazolium reduction in one minute. Catalase (CAT) was assayed by the reduction of dichromate in acetic acid to chromic acetate when heated in the presence of hydrogen peroxide $\left(\mathrm{H}_{2} \mathrm{O}_{2}\right)$ : the chromatic acetate thus produced is measured spectrophotometrically at 610nm (Sinha 1972). Glutathione peroxidase (GPx) was assayed as described by Rotruck et al. (1973), based on the reaction between glutathione remaining after the reaction of GPx and 5,5'-dithiobis(2)-nitrobenzoic acid) to give a compound that absorbs light at $412 \mathrm{~nm}$. Glutathione S-transferase (GST) was assayed by using 1-chloro-2,4-dinitrobenzene as substrate (Habig et al. 1974)). Glutathione reductase (GR), which utilizes NADP to convert oxidized glutathione (GSSG) to the reduced form of glutathione (GSH), was assayed as described by Staal et al. (1969), Glucose-6-phosphate dehydrogenase (G6PD) activity was measured by the method of Beutler (1983), where the increase in absorbance was measured when the reaction was start- 
ed by the addition of glucose-6-phosphate. Protein content was determined by the Lowry et al. (1951), method.

\subsection{Estimation of reduced glutathione and total sulfhy- dryl groups}

The level of reduced glutathione (GSH) was determined by the methods of Moron et al. (1979), based on the reaction with Ellman's reagent (19.8 mg DTNB in $100 \mathrm{ml} 0.1 \%$ sodium citrate). Total sulfhydryl groups (TSH) in tissue homogenate were measured by using the method of Ellman (1959).

\subsection{Determination of lipid peroxidation and protein carbonyl contents}

Lipid peroxidation in testes tissue was estimated spectrophotometrically by measuring the levels of thiobarbituric acid reactive substances (TBARS) and lipid hydroperoxides as described by Niehius and Samuelson (1968), and Jiang et al (1992) respectively. The level of protein carbonyls was determined by the method of Levine et al (1990).

\subsection{Assessment of membrane-bound ATPase}

The sediment after centrifugation was resuspended in ice cold Tris-HCL buffer $(0.1 \mathrm{M}) \mathrm{P}^{\mathrm{H}} 7.4$. This was used for the estimations of membrane-bound enzymes and protein content. The membrane bound enzymes such as $\mathrm{Na}^{+} / \mathrm{K}^{+}$-ATPase, $\mathrm{Mg}^{2+}$-ATPase and $\mathrm{Ca}^{2+}$ ATPase activity was assayed by estimating the amount of phosphorous liberated from the incubation mixture containing tissue homogenate, ATP and the respective chloride salt of the electrolytes (Bonting 1970, Ohnishi et al. 1982, Hjerten and Pan 1983). Total protein content was estimated by the method described by Lowry et al. (1951).

\subsection{Histopathological studies}

For qualitative analysis of testicular histology, the testes samples were fixed for $48 \mathrm{~h}$ at $10 \%$ formal-saline and dehydrated by passing successfully in different mixture of ethyl alcohol-water, cleaned with xylene and embedded in paraffin. Sections of tissue (5-6 $\mu \mathrm{m}$ thickness) were prepared by using a rotator microtome and stained with haematoxylin and eosin and in neutral deparafinated xylene (DPX) medium for microscopic observations.

\subsection{Electron microscopy}

Electron microscopic testes specimens were prefixed in $3 \%$ glutaraldehyde solution in $0.1 \mathrm{M}$ phosphate buffer for 1.5 hours, at $4^{\circ} \mathrm{C}$. Following this, they were washed in $0.15 \mathrm{M}$ phosphate buffer (pH 7.2) and post-fixed in $2 \%$ osmium tetroxide solution in 10 $\mathrm{mM}$ sodium phosphate buffer and left overnight. Dehydration was performed in acetone, and inclusion was done in the epoxy embedding resin Epon 812. The blocks were cut with an ultramicrotome type $\mathrm{LKB}$, at $70 \mathrm{~nm}$ thickness. The sections were doubly contrasted with solutions of uranyl acetate and lead citrate and analyzed with a TEM Tecnai 12 Biotwin electron microscope.

\subsection{Statistical analysis}

All the data were expressed as mean \pm SD $(n=6)$. The statistical significance was evaluated by one-way (ANOVA) using SPSS version 11.0 (SPSS, Cary, NC, USA) and the individual comparison were obtained Duncan's Multiple Range Test (DMRT).

\section{Results}

\subsection{Effect of as and DATS on morphological changes and biochemical analysis}

Table 1 shows the effect of As and DATS on food and water intake, body weight gain and organ-body weight ratio (\%) in control and experimental rats. In As treated rats, water and pellet diet consumption were significantly $(\mathrm{P}<0.05)$ decreased with a decrease in body weight gain. A significant $(\mathrm{P}<0.05)$ decrease in organ body weight ratio was noted in As treated rats. Pretreatment of DATS improved all these changes induced by As intoxication. The level of testis ALP, ACP and cholesterol increased significantly in arsenic treated rats when compared to the control rats (table 1). Pre-treatment of DATS in As exposed rats decreased the level of testis ALP, ACP and cholesterol when compared with As alone treated rats. No significant changes were found between control and DATS treated rats.

Table 1: Changes in Body Weight (BW), Testis Relative Weights, Level of Testes ALP, ACP and Cholesterol in Control and Experimental Rats

\begin{tabular}{|c|c|c|c|c|}
\hline Parameters & Control & As & DATS + As & DATS \\
\hline $\begin{array}{l}\text { Body } \\
\text { weight } \\
\text { Initial (g) }\end{array}$ & $182 \pm 7.62^{\mathrm{a}}$ & $180 \pm 6.21^{\mathrm{b}}$ & $180 \pm 6.59^{b}$ & $181 \pm 7.12^{\mathrm{c}}$ \\
\hline $\begin{array}{l}\text { BW gain } \\
\text { ( } \% \text { of initial } \\
\text { weight })\end{array}$ & $21.25 \pm 9.75^{\mathrm{a}}$ & $14.83 \pm 7.51^{\mathrm{b}}$ & $18.06 \pm 7.76^{\mathrm{c}}$ & $21.03 \pm 9.82^{\mathrm{a}}$ \\
\hline $\begin{array}{l}\text { Testis rela- } \\
\text { tive weights } \\
\text { (g/100g } \\
\mathrm{BW} \text { ) }\end{array}$ & $0.51 \pm 0.09^{\mathrm{a}}$ & $0.37 \pm 0.02^{\mathrm{b}}$ & $0.48 \pm 0.90^{\mathrm{c}}$ & $0.55 \pm 0.08^{\mathrm{d}}$ \\
\hline $\begin{array}{l}\text { Food intake } \\
(\mathrm{g} / 100 \mathrm{~g} \\
\mathrm{bw} / \mathrm{day})\end{array}$ & $12.05 \pm 1.34^{\mathrm{a}}$ & $8.36 \pm 0.67^{b}$ & $11.07 \pm 0.29^{\mathrm{a}}$ & $13.05 \pm 0.71^{\mathrm{a}}$ \\
\hline $\begin{array}{l}\text { Water } \\
\text { intake } \\
\text { (ml/rat/day) }\end{array}$ & $21.12 \pm 1.10^{\mathrm{a}}$ & $13.45 \pm 2.63^{\mathrm{b}}$ & $18.86 \pm 1.45^{\mathrm{c}}$ & $21.69 \pm 1.92^{\mathrm{a}}$ \\
\hline $\begin{array}{l}\text { ALP (mg } \\
\text { Pi/(g-hr)) }\end{array}$ & $2.71 \pm 0.26^{\mathrm{a}}$ & $6.14 \pm 0.42^{\mathrm{b}}$ & $3.37 \pm 0.21^{\mathrm{c}}$ & $2.39 \pm 0.20^{\mathrm{d}}$ \\
\hline $\begin{array}{l}\mathrm{ACP}(\mathrm{mg} \\
\mathrm{Pi} /(\mathrm{g}-\mathrm{hr}))\end{array}$ & $3.89 \pm 0.08^{\mathrm{a}}$ & $9.72 \pm 0.36^{\mathrm{b}}$ & $4.61 \pm 0.22^{\mathrm{c}}$ & $3.53 \pm 0.06^{\mathrm{d}}$ \\
\hline $\begin{array}{l}\text { Cholesterol } \\
\text { (mg/gm } \\
\text { tissue) }\end{array}$ & $3.37 \pm 0.14^{\mathrm{a}}$ & $5.71 \pm 0.34^{\mathrm{b}}$ & $4.06 \pm 0.24^{\mathrm{c}}$ & $3.05 \pm 0.16^{\mathrm{d}}$ \\
\hline
\end{tabular}

Values are mean \pm SD for 6 rats in each group. Values not sharing a common superscript letter $(\mathrm{a}-\mathrm{d})$ differ significantly at $\mathrm{p}<0.05$ (DMRT).

\subsection{Effect of as and DATS on plasma hormone levels, sperm concentration and sperm functions analysis (mo- tility and dead)}

The testicular hormone that is FSH, $\mathrm{LH}$ and testosterone levels in plasma illustrated in table 2. In arsenic treated rats the levels of FSH, LH and testosterone significantly $(\mathrm{P}<0.05)$ decreased when compared with the control rats. The decreased level of FSH, LH and testosterone were significantly increased when DATS is preadministered to as treated rats. Epididymal sperm concentration, motile sperm and dead sperm count were shown (Table 2) for As and DATS treatments. The intoxication of as exerted a significant $(\mathrm{P}<0.05)$ reduction in epididymal sperm concentration and motile sperm with increase dead sperm count. Pre-administration of DATS to as intoxicated rats caused a significant $(\mathrm{P}<0.05)$ increased in epididymal sperm concentration and motile sperm with decrease number of dead sperm. Interestingly, treatment of DATS alone shows a significant $(\mathrm{P}<0.05)$ increase in epididymal sperm concentration and motile sperm with decrease number of dead sperm when compared with control rats. No significant difference found between control and DATS treated rats. 
Table 2: Changes in Plasma Hormone Levels (LH mIU/ml, FSH mIU/ml and Testosterone ng/ml), Sperm Concentration and Sperm Function (Motility and Dead) in Control and Experimental Rats

\begin{tabular}{|c|c|c|c|c|}
\hline Parameters & Control & As & $\begin{array}{l}\text { DATS+A } \\
\text { S }\end{array}$ & DATS \\
\hline $\mathrm{LH}(\mathrm{mIU} / \mathrm{ml})$ & $\begin{array}{l}22.69 \pm 1.2 \\
4^{\mathrm{a}}\end{array}$ & $\begin{array}{l}11.46 \pm 2.5 \\
6^{\mathrm{b}}\end{array}$ & $\begin{array}{l}19.49 \pm 1.6 \\
3^{c}\end{array}$ & $\begin{array}{l}24.33 \pm 1.3 \\
2^{\mathrm{a}}\end{array}$ \\
\hline $\mathrm{FSH}(\mathrm{mIU} / \mathrm{ml})$ & $\underset{\mathrm{a}}{0.81 \pm 0.04}$ & $\begin{array}{l}0.35 \pm 0.07 \\
\mathrm{~b}\end{array}$ & $\begin{array}{l}0.74 \pm 0.05 \\
\mathrm{c}\end{array}$ & $\begin{array}{l}0.86 \pm 0.06 \\
\mathrm{a}\end{array}$ \\
\hline Testosterone (ng/ml) & $1.71 \pm 0.09$ & $\begin{array}{l}0.75 \pm 0.11 \\
\mathrm{~b}\end{array}$ & $1.49 \pm 0.12$ & $\frac{1.73 \pm 0.10}{a}$ \\
\hline $\begin{array}{l}\text { Sperm concentration } \\
\left(10^{6} / \mathrm{ml}\right)\end{array}$ & $\underset{\mathrm{a}}{163 \pm 6.81}$ & $\underset{b}{102 \pm 8.94}$ & $\int_{c} 157 \pm 7.87$ & $170 \pm 8.60$ \\
\hline $\begin{array}{ll}\text { Sperm } & \text { Motil- } \\
\text { func- } & \text { ity }\end{array}$ & $\begin{array}{l}87.6 \pm 3.92 \\
\text { a }\end{array}$ & $\begin{array}{l}41.3 \pm 2.37 \\
\mathrm{~b}\end{array}$ & $\begin{array}{l}82.1 \pm 3.88 \\
c\end{array}$ & $\begin{array}{l}89.6 \pm 3.42 \\
\mathrm{a}\end{array}$ \\
\hline $\begin{array}{l}\text { tion } \\
\text { Analy- Dead } \\
\text { sis }\end{array}$ & $\underset{\mathrm{a}}{27.4 \pm 1.06}$ & $\begin{array}{l}47.5 \pm 3.10 \\
b\end{array}$ & ${ }_{c}^{34.4 \pm 2.76}$ & $\underset{\mathrm{a}}{26.7 \pm 1.12}$ \\
\hline
\end{tabular}

Values are mean \pm SD for 6 rats in each group. Values not sharing a common superscript letter $(\mathrm{a}-\mathrm{d})$ differ significantly at $\mathrm{p}<0.05$ (DMRT).

\subsection{Effect of as and DATS on enzymatic antioxidant status}

Table 3 illustrates the activities of antioxidant and glutathione metabolizing enzymes in testes of control and experimental rats. As treated rats showed significant $(\mathrm{P}<0.05)$ reduce in the activities of SOD, CAT, GPx, GST, GR and G6PD as compared to control rats. Pre-treatment of DATS to as intoxicated rats significantly $(\mathrm{P}<0.05)$ restored the altered activities of all these enzymes when compared to as alone treated rats. Control and DATS alone treated rat show no significant difference.

Table 3: Effect of DATS on Enzymatic Antioxidant Status of Testis in Control and Experimental Rats

\begin{tabular}{|c|c|c|c|c|}
\hline Parameters & Control & As & DATS+AS & DATS \\
\hline $\begin{array}{l}\text { SOD } \\
\text { (Units/mg } \\
\text { protein) }\end{array}$ & $13.10 \pm 1.26^{\mathrm{a}}$ & $7.02 \pm 1.06^{\mathrm{b}}$ & $10.80 \pm 1.12^{\mathrm{c}}$ & $13.96 \pm 1.27^{\mathrm{a}}$ \\
\hline $\begin{array}{l}\text { CAT } \\
(\mu \mathrm{mol} / \mathrm{min} \\
\mathrm{mg} \text { protein })\end{array}$ & $7.38 \pm 1.01^{\mathrm{a}}$ & $4.19 \pm 0.43^{b}$ & $6.81 \pm 0.77^{\mathrm{c}}$ & $8.09 \pm 0.68^{\mathrm{d}}$ \\
\hline $\begin{array}{l}\mathrm{GPx} \\
(\mu \mathrm{g} / \mathrm{min} \mathrm{mg} \\
\text { protein) }\end{array}$ & $4.23 \pm 0.71^{\mathrm{a}}$ & $2.10 \pm 0.23^{b}$ & $3.77 \pm 0.19^{c}$ & $4.28 \pm 0.86^{\mathrm{a}}$ \\
\hline $\begin{array}{l}\text { GST } \\
(\mu \mathrm{mol} / \mathrm{min} \\
\mathrm{mg} \text { protein })\end{array}$ & $12.04 \pm 0.83^{\mathrm{a}}$ & $6.42 \pm 0.77^{b}$ & $10.56 \pm 0.79^{c}$ & $12.38 \pm 0.92^{\mathrm{a}}$ \\
\hline $\begin{array}{l}\text { GR } \\
(\mu \mathrm{mol} / \mathrm{min} \\
\mathrm{mg} \text { protein })\end{array}$ & $0.53 \pm 0.03^{\mathrm{a}}$ & $0.22 \pm 0.01^{\mathrm{b}}$ & $0.45 \pm 0.03^{\mathrm{c}}$ & $0.58 \pm 0.03^{\mathrm{a}}$ \\
\hline $\begin{array}{l}\text { G6PD } \\
(\mu \mathrm{mol} / \mathrm{min} \\
\mathrm{mg} \text { protein })\end{array}$ & $1.29 \pm 0.41^{\mathrm{a}}$ & $0.51 \pm 0.04^{b}$ & $1.06 \pm 0.23^{\mathrm{c}}$ & $1.27 \pm 0.25^{\mathrm{a}}$ \\
\hline
\end{tabular}

Values are mean \pm SD for 6 rats in each group. Values not sharing a common superscript letter $(\mathrm{a}-\mathrm{d})$ differ significantly at $\mathrm{p}<0.05$ (DMRT).

\subsection{Effect of as and DATS on thiol based antioxidant status}

Table 4 depicts the levels of GSH, TSH and GSSG in control and experimental rats' testes. The levels of GSH and TSH significantly $(\mathrm{P}<0.05)$ decreased along with the increased level of oxidized GSH in as treated rats when compared with the control rats. Preadministration of DATS with as shown a significant $(\mathrm{P}<0.05)$ increased in the level of GSH and TSH with reduced level of GSSG in testes when compared to as expose rats.
Table 4: Changes in Non-Enzymatic Antioxidant Status of Testis in Control and Experimental Rats

\begin{tabular}{lllll} 
Parameters & Control & As & $\begin{array}{l}\text { DATS }+ \\
\text { As }\end{array}$ & DATS \\
\hline $\begin{array}{l}\text { GSH }(\mu \mathrm{g} / \mathrm{mg}) \\
\text { GSSG }\end{array}$ & $3.1 \pm 0.15^{\mathrm{a}}$ & $1.38 \pm 0.07^{\mathrm{b}}$ & $2.84 \pm 0.1^{\mathrm{c}}$ & $3.17 \pm 0.16^{\mathrm{a}}$ \\
$(\mu \mathrm{mol} / \mathrm{min}$ & $0.31 \pm 0.014^{\mathrm{a}}$ & $0.69 \pm 0.040^{\mathrm{b}}$ & $0.4 \pm 0.018^{\mathrm{c}}$ & $0.3 \pm 0.010^{\mathrm{a}}$ \\
$\mathrm{mg}$ protein $)$ & & & & \\
GSH/GSSG & $9.66 \pm 0.51^{\mathrm{a}}$ & $2.11 \pm 0.36^{\mathrm{b}}$ & $7.64 \pm 0.5^{\mathrm{c}}$ & $9.71 \pm 0.49^{\mathrm{a}}$ \\
TSH $(\mu \mathrm{g} / \mathrm{mg})$ & $7.16 \pm 0.55^{\mathrm{a}}$ & $4.24 \pm 0.43^{\mathrm{b}}$ & $6.35 \pm 0.29^{\mathrm{c}}$ & $7.2 \pm 0.61^{\mathrm{a}}$ \\
\hline
\end{tabular}

Values are mean \pm SD for 6 rats in each group. Values not sharing a common superscript letter $(\mathrm{a}-\mathrm{c})$ differ significantly at $\mathrm{p}<0.05$ (DMRT).

\subsection{Effect of as and DATS on oxidative stress markers}

Figure 1 shows the changes in the levels of testicular oxidative stress markers viz., lipid peroxidation, protein carbonyl content levels in testes of control and experimental rats. Arsenic exposed rats showed a significant $(\mathrm{P}<0.05)$ increase in the levels of TBARS, lipid hydroperoxides and protein carbonyl contents when compared to control rats. Pre-administration of DATS in As treated rats showed a significant $(\mathrm{P}<0.05)$ decreased in the levels TBARS, lipid hydroperoxides and protein carbonyl contents when compared with As treated rats. There is no significant difference between control and DATS treated rats.

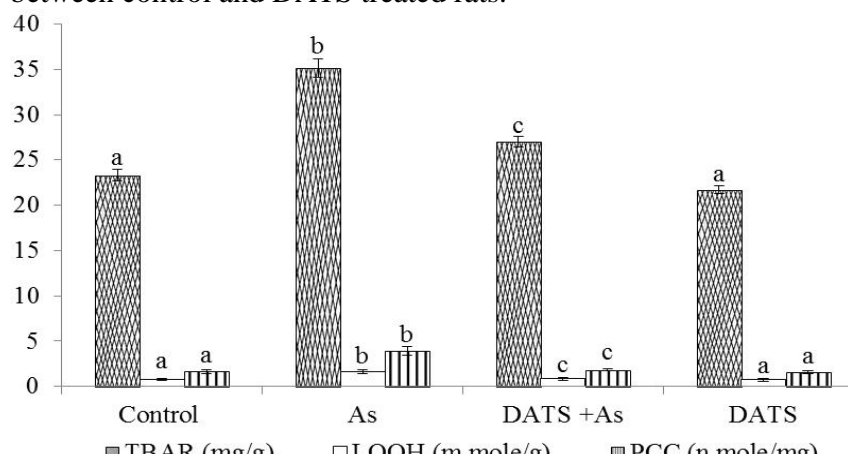
Fig. 1: Changes in the Level of Oxidative Stress Markers of Testis Tissue in Control and Experimental Rats

\subsection{The effect of as and DATS on membrane bound ATPases}

Figure 2 shows the activities of hepatic total ATPase, $\mathrm{Na}^{+} / \mathrm{K}^{+}$ATPase, $\mathrm{Mg}^{2+}$ - ATPase and $\mathrm{Ca}^{2+}$-ATPase in the testes of control and experimental rats. The activities of these membranes bound ATPases in the testes tissue of as treated rats were significantly ( $p$ $<0.05)$ decreased when compared to the control rats. Pretreatment of DATS $(80 \mathrm{mg} / \mathrm{kg}$ bw/day) before as intoxication significantly $(\mathrm{p}<0.05)$ restored the levels of the entire membrane bound ATPases when compared to as intoxicated rats. No significant changes observed between control and DATS alone treated rats.

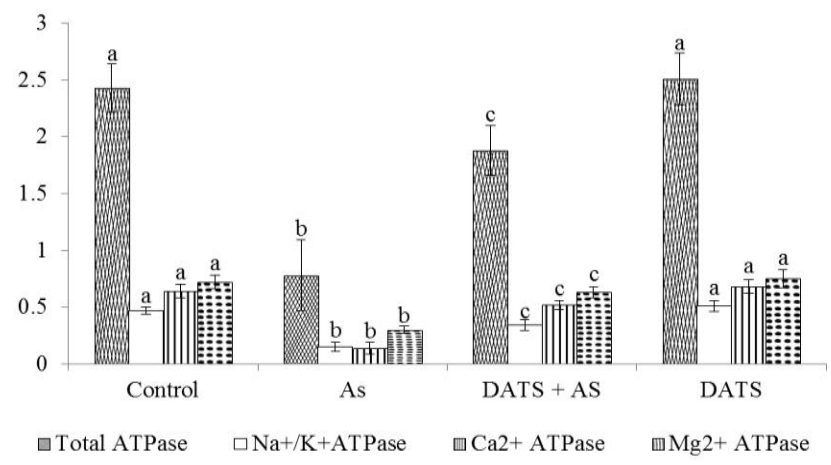

Fig. 2: Changes in the Status Membrane Bound Atpases of Testis Tissue in Control and Experimental Rats 


\subsection{Effect of as and DATS on histological changes}

The testes of control rats exhibited normal testicular structures on histological examination (Fig. 3A). In DATS treated groups it shows normal spermatogenesis (Fig. 3D). Considerably the as treatment damaged the histological structure of the testes and it is correlated with the oxidative stress induced by it. The seminiferous tubules swell and enlarge with focal hemorrhage and necrosis in the interstitial stromes (Fig. 3B). The histology of testes was found to be similar to control in DATS pre-administration groups and it found to display spermatogenesis with a number of spermatozoa, spermatids, spermatocytes and interstitial cell (Fig. 3C).
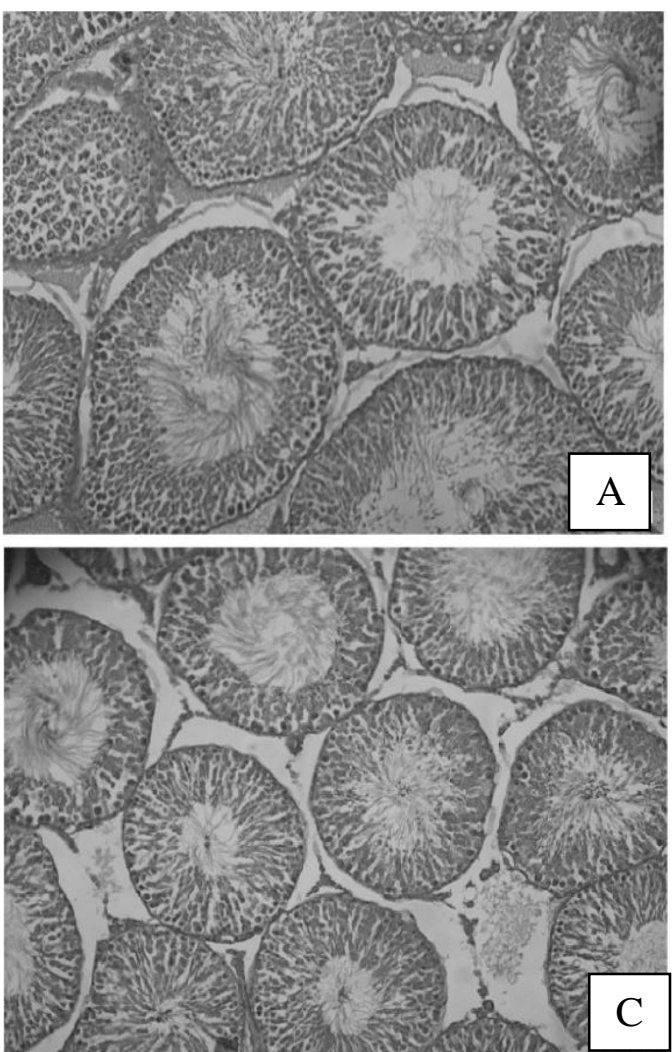
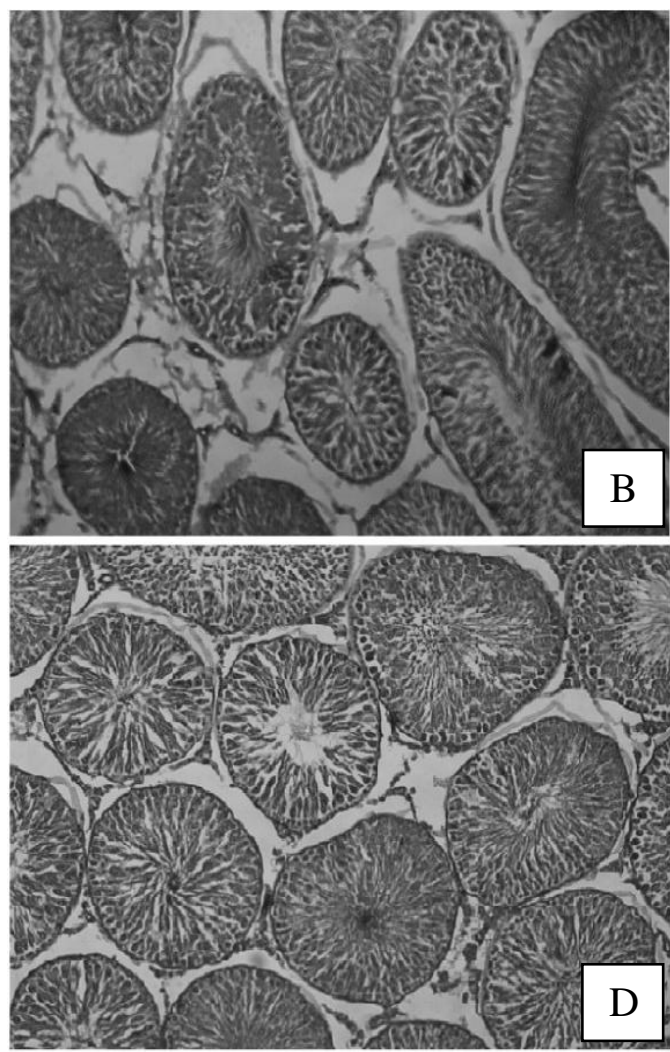

Fig. 3: (A) Histopathology of Control Rat Displaying Normal Histological Architecture of Seminiferous Tubules, Sertoli Cell with Spermatogenesis (H\&E, 100X). (B) Section of s Treated Rat Displayed Marked Disorder of the Normal Architecture of the Testicular Tissues, where the Seminiferous Tubules Swell and Enlarge with Focal Hemorrhage and Necrosis in the Interstitial Stromes (H\&E, 100X). (C) Testis Section of DATS + as Treated Rats Showing Significant Improvement of Histological Architecture with Normal Seminiferous, Spermatocytes And Interstitial Cell (H\&E, 100X). (D) Testis Section of DATS Alone Treated Rats Showing the Normal Histological Architecture Pattern of Seminiferous Tubules with Normal Spermatogenesis and It Found to Seen Spermatogenesis with Number of Spermatozoa, Spermatids, Spermatocytes and Interstitial Cell (H\&E, 100X).

\subsection{Effect of as and DATS on electron microscopic ex- amination of rat testis.}

Figure 4 shows the images of electron microscopic study. The control rat testis exhibit normal histology where seminiferous tubules, interstitial cells and various stages of spermatogenesis are clearly visible (Fig. 4A). In arsenic alone treated rat the irregular membrane of the spermatogonia nucleus with vacuolated cytoplasm appeared where endoplasmic reticulum found to dilate and mitochondria are seem to swell and vacuolated (Fig. 4B). Pretreatment of DATS with arsenic treated rats altered all these histological changes observed under electron microscopic examination and it is supported by the clearly visible spermatic nucleus, endoplasmic reticulum and mitochondria that have been recovered by DATS lucratively (Fig. 4C). The electron microscopic images of DATS alone treated rat display similar structure with that of the control rat testes (Fig. 4D).

\section{Discussion}

Arsenic can induce male reproductive toxicity such as dosedependent decrease in testes and accessory sex organ weights. It may also reduce the epididymal sperm count, viability, and motility. Normal morphology and the activity of antioxidant defense system (Momeni and Najmeh 2012). In the present investigation also food and water intake, body weight gain and organ-body weight ratio (\%) was found to reduce and it accordance with the report of Muthumani and Miltonprabu (2012). DATS supplementation restored all these morphological changes (Sumedha and Miltonprabu 2013), and protect the testes from As induced testicular changes.

The level of testis ALP, ACP and cholesterol increased significantly in arsenic treated rats compared to the control when rats. In the seminiferous tubule, basement membrane and interstitial membrane the ALP had detected and it takes a very important role in transporting material from Sertoli cells to various germinal cells, in the testicular metabolism and differentiation and proliferation of germinal epithelium. Alkaline phosphatase helps in synthesis of testicular hormones and spermatogenesis. Arsenic introverted the spermatogenic development and as a result the unexploited alkaline phosphatase was increased in the testis. Kaur et al. (1999) also reported that the increased activity of testicular alkaline phosphatase and acid phosphatase in treating rats reflects testicular degeneration, which may be an indication of lytic activity and it is similar to our results. Acid phosphatase doles-out as a biochemical marker for specific androgen-dependent steps in spermatogenesis and it is present in the lysosome of Sertoli cells, spermatocytes and spermatids (Garima and Madhu 2012). The lysosomal breakdown of testicular cells or to increase phagocytic activity of the Sertoli cells is the main reason for the increase activity of acid phosphatase in arsenic treated rats. The higher levels of acid phosphatase may be stated to correlate with testicular damage, germ cell loss and arrest of spermatogenesis, which leads to decreased of testicular weight and sperm count in as treated rats. 
Pre-treatment of DATS decreased the level of testis ALP, ACP and cholesterol. In our findings, DATS regulates the activities of those enzymes by protecting free radicals responsible for oxidative stress and the production of ROS as supported by restoration of non-enzymatic and enzymatic antioxidants in the testes. Pre- treatment of DATS effectively stabilizes the spermatogenic development and spermatogeniesis and it is supported by the reduced levels of ALP and ACP and protects the testes against the toxic effects of As (Miltonprabu and Sumedha 2013).
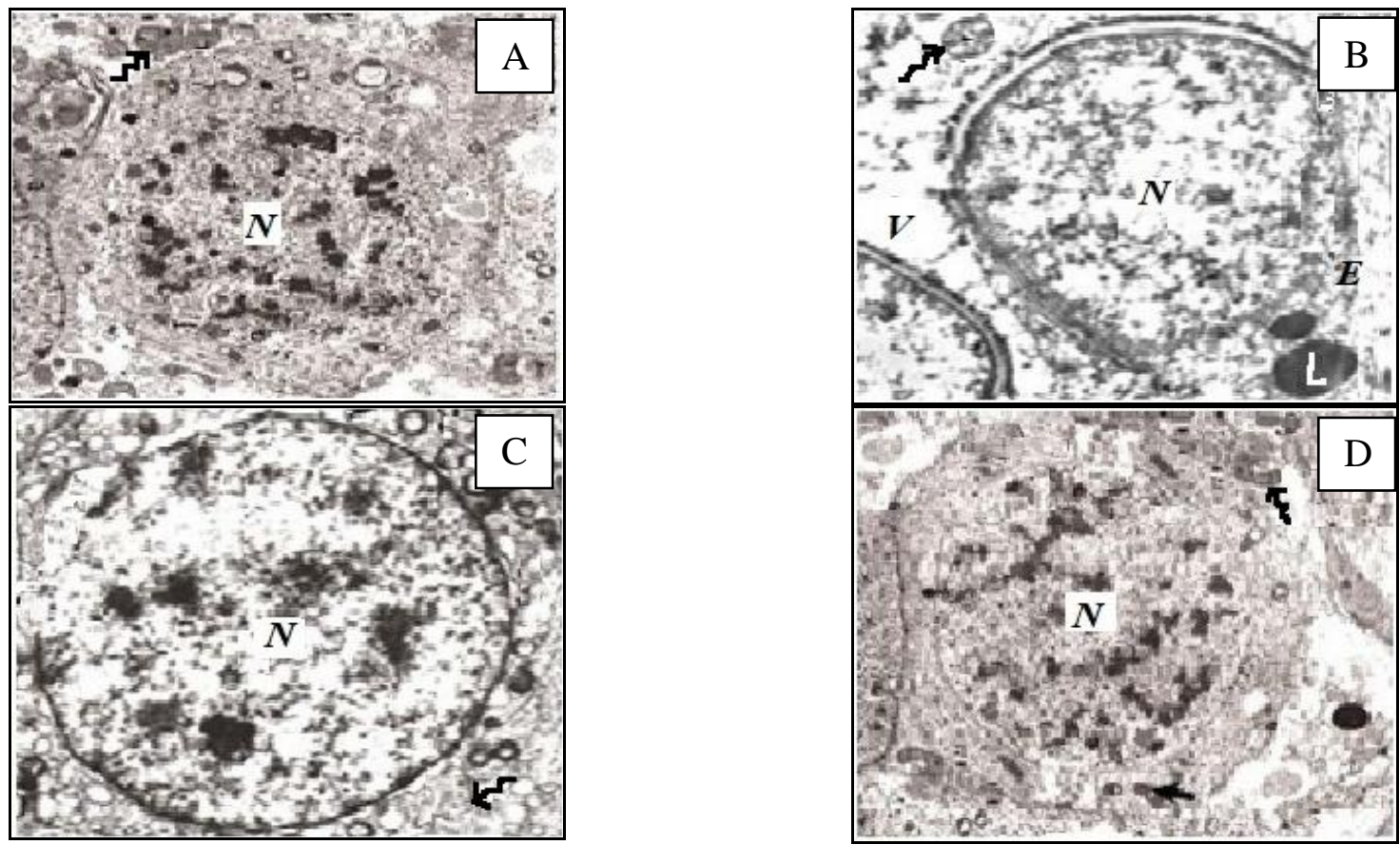

Fig. 4: (A) Normal Histology of Control Rat Testis where Seminiferous Tubules, Interstitial Cells and Various Stages of Spermatogenesis are Clearly Visible (X10000- N-Spermatogonia Nuclei; Arrow-Mitochondria). (B) Image of Arsenic Alone Treated Rat Displaying Irregular Membrane of Spermatogonia Nucleus with Vacuolated Cytoplasm where Endoplasmic Reticulum Found to Dilate and Mitochondria are Seem to Swollen and Vacuolated (X12000- N-Spermatogonia Nucleus;Arrow-Mitochondria;L-Droplet of Lipids, V-Vacuolated Cytoplasm). (C) Altered Histological Changes Observed In DATS Pre-Treatment to Arsenic Treated Rats Under Electron Microscopic Examination (X12000- N-Spermatid Nuclei; Arrow-Mitochondria). (D) The Testis of DATS Alone Treated Rat, Showing Spermatogonia Nuclei (N), Mitochondria (Arrows) X8000.

Cholesterol the originator for androgen production in the testis is present in Leydig cells and spermatogenic cells, including spermatocytes. The most important step in steroidogenesis is the conversion of cholesterol to pregnenolone. The cholesterol level also showed a highly significant increase in arsenic intoxicated rat. Our results is accordance with the report of Nair et al. (1987), where the elevated cholesterol level has been attributed to its decreased utilization for steroidogenesis which may be due to pituitary repression or a direct inhibitory action of target tissue. Pre-treatment of DATS significant reduced the testis cholesterol level and it is due its antihyperlipidaemic activity (Lii et al. 1991) and DATS has been found to reduce cholesterol level in liver and plasma of arsenic treated rats (unpublished lab report).

In our findings the level of luteinizing hormone ( $\mathrm{LH})$, folliclestimulating hormone (FSH) and testosterone concentration was found to decrease in As exposed rats when compared to control. Changes in the level of luteinizing hormone (LH), folliclestimulating hormone (FSH), testosterone and also massive degeneration of the germ cells in testis tissue are reported to be an account for arsenic toxicity. Oxidative stress and the generation of reactive oxygen species (ROS) could also be a consequence of arsenic exposure. ROS generation as well as the binding of arsenic to protein thiol groups can alter many protein functions. The integrity of sperm DNA is an important factor for the success of fertilization as well as normal development of the embryo, fetus and child. Several lines of studies have shown the effect of environmental contaminant arsenic on DNA damages through inducing oxidative stress and the generation of ROS (Momeni and Najmeh 2012). Pre-treatment of DATS in As treated rats increased the level of luteinizing hormone (LH), follicle-stimulating hormone (FSH) and testosterone concentration, showing its ability to protect the male fertility damaged by arsenic as it can scavenge the free radical and ROS induced by As (Sumedha and Miltonprabu 2013).
Arsenic was found to give hindrance in testes sperm formation and sperm function as it is confirmed by its ability to reduced sperm count, sperm motility and increase sperm dead when compared to control rats. Significant decrease in sperm counts was also observed in arsenic exposed in rats. Mammalian sperm contain large amounts of thiol-rich proteins in the flagellum, which maintains sperm motility and stability. Arsenic is a well-known thiolinhibiting metalloid. The decrease in sperm motility in the present study may be due to accumulation of arsenic in the epididymis where the sperm matures and acquires motility and due to low availability of testosterone in As treated (Muthumani and Miltonprabu 2012, Ali et al. 2013). It might be possible that the electrophilic nature of the arsenic it binds to sulphydryl groups on proteins and thereby inhibits enzyme activity affecting reproductive hormone secretion (Ali et al. 2013). Pre-treatment with DATS to as exposed rats significantly increased sperm count, sperm motility and decrease sperm dead when compared with As alone treated rats. This ability of DATS may be due to the reduced accumulation of As in the epididymis as DATS chelate with As forming complex and enhance As excretions as it can acts as multidentate ligands likely due to their ability to coordinate with several sulfur atoms at a time (Sumedha and Miltonprabu 2013).

The antioxidant enzymes such as SOD, ACT, GPx, GST and G6PD constitute the secondary line of enzymatic antioxidant defense against ROS induced oxidative stress. In the present study as a treatment severely decreased the levels of these antioxidant enzymes strongly the oxidative stress, which is in connection with the reports of (Morakinyo et al. 2010). Pre-treatment of DATS significantly restored the antioxidant enzyme defense in as exposed rat testes via its strong antioxidant property. DATS may act as an antioxidant by scavenging ROS and also improving the endogenous antioxidant system in As treated rats (Sumedha and Miltonprabu 2013). Reduced level of antioxidant status also was found in our study. Moreover the DATS ability to acts as 
multidentate ligands possibly due to their capacity to coordinate with several sulfur atoms at a time and the ability to activate Nrf2 may contribute to developing the tissue thiol groups, which could be linked with a lessening in As provoked oxidative threat and increased antioxidant status in DATS pre-supplemented As treated rats (Muthumani and Miltonprabu 2012).

The thiol based antioxidant system is the primary line of defense against oxidative stress. Arsenic induced oxidative stress is strongly suggested with the decreased levels of reduced GSH, TSH and increased level of oxidized GSH. DATS supplementation in as treated rats, restored the depleted non-enzymatic antioxidant near normalcy, suggesting the antioxidant nature of DATS and it has been already reported that DATS increased the level of the nonenzymatic antioxidant system ((Sumedha and Miltonprabu 2013). The elevated level of lipid peroxidation products such as TBARS, $\mathrm{LOOH}$ and PC in the testicular tissue of As exposed rats in the present investigation noticeably discovered the oxidative stress and failure of the antioxidant system which is agreed with the findings of Morakinyo et al. (2010). In our present study, the intoxication of As in all the experimental rats caused a significant increase in protein carbonyl suggesting a failure of antioxidant defense system to prevent protein oxidation. Pre-treatment of DATS to As treated rats significantly decreased the extend of oxidative stress by means of its strong metal chelating and antioxidant possessions and it is accordance with Miltonprabu and Sumedha (2013).

In the present study, a significant decrease in the activities of membrane-bound ATPases in the testis was observed in As-treated rats when compared to the control rats. Decreased activity of $\mathrm{Na}+$ / $\mathrm{K}+$-ATPase could be due to enhanced lipid peroxidation by free radicals on as induction, because $\mathrm{Na}+/ \mathrm{K}+-$ ATPase is an $\mathrm{SH}-$ group-containing enzyme and is lipid dependent. Decreased activity of $\mathrm{Na}+/ \mathrm{K}+-$ ATPase can lead to a decrease in sodium efflux, thereby altering membrane permeability. The disruption of membrane permeability or fragmentation of the membrane leads to the leakage of $\mathrm{Ca}^{2+}$ ions into cells thereby potentiating irreversible cell destruction. The $\mathrm{Ca}^{2+}$ overload medicated arsenic also decreased the $\mathrm{Ca}^{2+}$ ATPase activity in cell membranes. It is generally accepted that due to the high affinity for $\mathrm{SH}$ groups, arsenic binds avidly to various enzyme proteins and inactivates them $\mathrm{Mg}^{2+}$ ATPase activity is involved in other energy-requiring processes in the cell and its activity is sensitive to lipid peroxidation Miltonprabu and Sumedha (2013). Pre-treatment of DATS with arsenic-intoxicated rats significantly reduced the lipid peroxidation in testis and sustained the activities of membrane-bound enzymes. This may be due to the ability of DATS to protect the $\mathrm{SH}$ groups from oxidative damage through the inhibition of peroxidation of membrane lipids and stabilization of the membrane.

The biochemical findings of the present study also coincided with the histological studies inducing severe pathological changes in testis with variations in the structure and shape of seminiferous tubules, where the seminiferous tubules swell and enlarge with focal hemorrhage and necrosis in the interstitial stromes. The increased oxidative stress induced by As may be dependable for the As intervene pathological alteration in the testes. The histology of testes was found to be similar to control in DATS supplemented groups and it found to be seen spermatogenesis with a number of spermatozoa, spermatids, and spermatocytes and interstitial. In As treated rats supplementation of DATS restored the drastic pathological changes. The antioxidant membrane stabilizing and metal chelating property of DATS afforded a significant protection and restores the normal architecture of the as treated rat testes.

The control rat testis exhibit normal histology where seminiferous tubules, interstitial cells and various stages of spermatogenesis are clearly visible. The irregular membrane of the spermatogonia nucleus with vacuolated cytoplasm appeared where endoplasmic reticulum found to dilate and mitochondria are seem to swell and vacuolated in arsenic alone treated rat. Pre-treatment of DATS with arsenic treated rats altered all these histological changes observed under electron microscopic examination and it is supported by the clearly visible spermatic nucleus, endoplasmic reticulum and mitochondria that have been recovered by DATS profitably.

\section{Conclusion}

The present study pointed out that DATS significantly pacify the harmful effects of As in the testes by reducing the testicular oxidative stress, elevating the levels of non-enzymatic antioxidants and enhanced the activities of antioxidant enzymes through which it improves and restores the normal function of the testicular tissue which was altered by As.

\section{Acknowledgement}

This research work was supported by University Grants Commission (UGC), Major project research grant funded by the Government of India. New Delhi (F.No:41-171/2012 (SR) dated 09/07/2012). The authors are deeply thankful to the funding agency for the constant financial and moral support towards the successful completion of this study.

\section{References}

[1] Ali M, Shabbir AK, Pushplata D, Nath A, Singh JK, Kumar R \& Kumar A (2013) Impact of arsenic on testosterone synthesis pathway and sperm production in mice. Innovative Journal of Medical and Health Science 3, 185 - 189.

[2] Beutler E (1983) Active transport of glutathione disulfide from erythrocytes. In: Functions of Glutathione-Biochemical, Physiological, Toxicological and Clinical Aspects, edited by Larson A, Orrenius S, Holmgren A, Mannerwik B, Raven Press, New York, USA 65.

[3] Bonting SL (1970) Membrane and ion transport, presence of enzyme systems in mammalian tissues. Wiley Interscience, London 257-263.

[4] Chang SI, Jin B, Youn P, Park C, Park JD \& Ryu DY (2007) Arsenicinduced toxicity and the protective role of ascorbic acid in mouse testis. Toxicology and applied pharmacology 218, 196-203.

[5] Das J, Jyotirmoy G, Prasenjit M, Mahua S \& Sil PC (2009) Taurine protects rat testes against $\mathrm{NaAsO} 2$-induced oxidative stress and apoptosis via mitochondrial dependent and independent pathways. Toxicology Letters 187, 201-210.

[6] Ellman GL (1959). Tissue sulfhydryl groups. Archives of Biochemistry and Biophysics 82, 70-77.

[7] Evans G \& Maxwell WMC (1987) Handling and examination of semen. In: Salamon's Artificial Insemination of Sheep and Goats, edited by Maxwell WMC, Butterworths, Sidney 93-106.

[8] Fiske CH \& Subbarow Y (1925) The colorimetric determination of phosphorus. The Journal of Biological Chemistry 66, 375-400.

[9] Garima S \& Madhu K (2012) Antioxidant and modulatory role of Chlorophytum borivilianum against arsenic induced testicular impairment. Journal of Environmental Sciences 24, 2159-2165.

[10]Habig WH, Pabst MJ \&Jakpoly WB (1974) Glutathione transferase: a first enzymatic step in mercapturic acid and formation. The Journal of Biological Chemistry 249, 7130-7139.

[11]Hjerten S \& Pan H (1983) Purification and characterization of two forms of low affinity Ca2+-ATPase from erythrocyte membrane. Biochimica Biophysica Acta-Biomembranes 728, 281-288.

[12]Jiang ZY, Hunt JV \& Wolff SD (1992) ferrous ion oxidation in the presence of xylenol orange for detection of lipid hydroperoxide in low density lipoprotein. Analytical Biochemistry 202, 384-389.

[13]Kakkar P, Das B \& Viswanathan PN (1984) A modified spectroscopic assay of superoxide dismutase. Indian Journal of Biochemistry and Biophysics 21, 130-132.

[14]Kaur R, Dhanju CK \& Kaur K (1999) Effects of dietary selenium on biochemical composition of rat testis. Indian Journal of Experimental Biology 37, 509-511.

[15]Kind EJ \& Wolten I (1959) Microanalysis. In Medical Biochemistry. Churchill, London 42-57.

[16]Levine RL, Garland D, Oliver CN, Amic A, Climent I, Lenz AG, Ahn BW, Shaltiel S \& Stadtman ER (1990) Determination of carbonyl content in oxidatively modified proteins. Methods in Enzymology $186,464-478$.

[17]Lii CK, Huang CY, Chen HW, Chow MY, Lin YR, Huang CH \& Tsai CW (2012) Diallyl trisulfide suppresses the adipogenesis of 3T3-L1 preadipocytes through ERK activation. Food and Chemical Toxicology $50,478-484$. 
[18]Linder RE, Strader LF \& Mcelroy WK (1986) Measurement of epididymal sperm motility as a test variable in the rat. Bulletin of Environmental Contamination and Toxicology 36, 317-324.

[19]Lowry OH, Rosenbrough NJ, Farr AI \& Randall RJ (1951) Protein measurement with the folinphenol reagent. The Journal of Biological Chemistry 193, 265-275.

[20]Mehranjani MS \& Hemadi M (2007) The effects of sodium arsenite on the testis structure and sex hormones in vasectomised rats. Iranian Journal of Reproductive Medicine 5, 127-133.

[21]Milton SP \& Sumedha NC (2013) Ameliorative effect of diallyl trisulphide on arsenic-induced oxidative stress in rat erythrocytes and DNA damage in lymphocytes. Journal of Basic and Clinical Physiology and Pharmacology DOI 10.1515/jbcpp-2013-0047 p 1-17.

[22]Momeni HR \& Najmeh E (2012). Effect of vitamin E on sperm parameters and DNA integrity in sodium arsenite-treated rats. Iranian Journal of Reproductive Medicine 10, 249-256.

[23]Morakinyo AO, Achema PU \& Adegoke OA (2010) Effect of Zingiber Officinale (Ginger) on Sodium Arsenite-Induced Reproductive Toxicity in Male Rats. African Journal of Biomedical Research $13,39-45$.

[24]Moron MS, Despierre JW \& Minnervik B (1979) Levels of glutathione, glutathione reductase and glutathione S-transferase activities in rat lung and liver. Biochimica Biophysica Acta-Biomembranes 582, 67-78.

[25]Muthumani M \& Miltonprabu S (2012) Silibinin ameliorates oxidative stress mediated testicular damage by arsenic in rats. Asian Pacific Journal of Tropical Biomedicine 1, 1-7.

[26]Nair N, Edward MS, Bedwal RS \& Mathur RS (1987) Effect of adrenalectomy and adrenalectomy hydrocortisone treatment of zinc, biochemical parameters and histology of testes of rats. Indian Journal of Experimental Biology 25, 651-659.

[27]Niehius WG \& Samuelson D (1968) Formation of malondialdehyde from phospholipid arachidonate during microsomal lipid peroxidation. European Journal of Biochemistry 6, 126-130.

[28]Ohnishi T, Suzuki T, Suzuki Y \& Ozawa K (1982) A comparative study of plasma membrane $\mathrm{Mg} 2+-\mathrm{ATPa} e$ activities in normal, regenerating and malignant cells. Biochimica et Biophysica ActaBiomembranes 684, 67-74.

[29]Rotruck JT, Pope AL \& Ganther HE (1973) Selenium: biochemical role as a component of glutathione peroxidase purification assay. Science 179, 588-590.

[30]Sarkar M, Chaudhuri GR, Chattopadhyay A \& Biswas NM (2003) Effect of sodium arsenite on spermatogenesis, plasma gonadotrophins and testosterone in rats. Asian Journal of Andrology 5, 27-31.

[31] Sharma G \& Kumar M (2011) Morphometrical study of seminiferous tubules of mice after using arsenic and Chlorophytum borivilianum. Pharmacologyonline 2, 348-359.

[32] Sinha AK (1972) Colorimetric assay of catalase. Analytical Biochemistry 47, 389-394.

[33]Skakkeback NE, Negro-Villar A, Michal F \& Fathalla M (1991) Impact of the environment on reproduction health report and recommendation of a WHO. International Workshop, Danish Medical Bulletin $38,425-426$

[34]Staal GEJ, Visser J \& Veeger C (1969) Purification and properties of glutathione reductase of human erythrocytes. Biochimica et Biophysica Acta- Biomembranes 185, 39-48.

[35] Sumedha NC \& Miltonprabu S (2013) Antioxidant efficacy of diallyl trisulfide on arsenic-induced toxicity in rats: an in vivo and in vitro study. International Journal of Toxicology and Applied Pharmacology 3, 33-38. 